\title{
Translational Review
}

\section{Advances in Mucous Cell Metaplasia A Plug for Mucus as a Therapeutic Focus in Chronic Airway Disease}

\author{
David R. Curran ${ }^{1}$ and Lauren Cohn ${ }^{1}$ \\ ${ }^{1}$ Section of Pulmonary and Critical Care, Yale University School of Medicine, New Haven, Connecticut
}

\begin{abstract}
Mucous cell metaplasia is induced in response to harmful insults and provides front-line protection to clear the airway of toxic substances and cellular debris. In chronic airway diseases mucous metaplasia persists and results in airway obstruction and contributes significantly to morbidity and mortality. Mucus hypersecretion involves increased expression of mucin genes, and increased mucin production and release. The past decade has seen significant advances in our understanding of the molecular mechanisms by which these events occur. Inflammation stimulates epidermal growth factor receptor activation and IL-13 to induce both Clara and ciliated cells to transition into goblet cells through the coordinated actions of FoxA2, TTF-1, SPDEF, and GABA ${ }_{A}$. Ultimately, these steps lead to up-regulation of MUC5AC expression, and increased mucin in goblet cell granules that fuse to the plasma membrane through actions of MARCKS, SNAREs, and Munc proteins. Blockade of mucus in exacerbations of asthma and chronic obstructive pulmonary disease may affect morbidity. Development of new therapies to target mucus production and secretion are now possible given the advances in our understanding of molecular mechanisms of mucous metaplasia. We now have a greater incentive to focus on inhibition of mucus as a therapy for chronic airway diseases.
\end{abstract}

Keywords: mucus; goblet cell; airway epithelium; asthma; COPD

Airway mucus serves critical functions in host defense. The airway luminal surface is coated by a multiphase mucus film that has a superficial periciliary layer and an overlying gel layer. In healthy subjects, the viscoelastic gel layer is propelled from the lower airways toward the larynx by the constant beating of cilia in the underlying, less viscous, periciliary layer. This mucociliary escalator thus permits inhaled particles and pathogens entrapped in the gel layer to be eliminated through coughing or swallowing upon reaching the upper airway.

Since the dawn of medicine, mucus has been central to good health. The Hippocratic Corpus taught that maintenance of normal phlegm was crucial to the health of the individual (1). In infection Osler described how "catarrhal inflammation and a heavy coating of mucus lessen (ciliated epithelial cell) activity and hence reduce their protective power" (2). Mucus hyperproduction causes cough and wheezing, can impair mucociliary clearance causing retention of pathogens and toxic particles, and may also result in airway obstruction leading to ventilationperfusion mismatching. Chronic airway diseases, such as

(Received in original form May 3, 2009 and in final form May 14, 2009)

This work was funded by National Institutes of Health RO164040 (L.C.) and the Seltzer Family Translational Research Fund (L.C.).

Correspondence and requests for reprints should be addressed to Lauren Cohn, M.D., Section of Pulmonary and Critical Care, Yale University School of Medicine, New Haven, CT 06520. E-mail: Lauren.cohn@yale.edu

Am J Respir Cell Mol Biol Vol 42. pp 268-275, 2010

Originally Published in Press as DOI: 10.1165/rcmb.2009-0151TR on June 11, 2009

Internet address: www.atsjournals.org

\section{CLINICAL RELEVANCE}

This is a translational review that brings together a decade's worth of studies to enhance our understanding of the processes by which mucous metaplasia occurs in health and chronic airway diseases.

asthma, cystic fibrosis (CF), and chronic obstructive pulmonary disease (COPD) are associated with a mucus hypersecretory phenotype, which contributes significantly to the morbidity and mortality related to these conditions. Does excess mucus production in chronic lung disease provide any benefit? What would happen if mucus were inhibited? These questions can now be more carefully assessed given the past decade's advances in our understanding of the pathways regulating mucus production and secretion.

\section{MUCUS COMPOSITION}

Mucus is composed of water, ions, lipids, proteins, and complex, macromolecular glycoproteins called mucins, which impart viscoelastic and gel-forming properties to mucus (3). More than 20 mucin genes have been identified, and 12 of these have been shown to be expressed in the respiratory epithelium (4). There are two structurally and functionally distinct classes of mucin: membrane-bound mucins and secreted mucins. Membrane mucins, which have transmembrane and cytosolic domains, are tethered to the plasma membrane, where they participate in functions such as cellular adhesion, pathogen binding, and signal transduction $(5,6)$. Shearing forces, proteolytic cleavage, or synthesis of alternative splice variants lacking the transmembrane domain can result in release of membrane mucins into the mucous layer (7). Secreted mucins are synthesized in epithelial cells and stored in intracellular secretory granules until stimulated for release by regulated exocytosis. The gel-forming mucins, MUC5AC and MUC5B, are the most prominent secreted mucins in the respiratory tract. These are huge molecules characterized by multidomain polypeptide chains with thousands of amino acid residues; large, heavily O-glycosylated apoprotein cores; and cysteinerich $\mathrm{N}$ - and $\mathrm{C}$ - terminal domains that permit disulfide-bond mediated oligomerization. When secreted, gel-forming mucins form a dense macromolecular matrix providing the adhesive and space-occupying properties of the mucous gel layer (8).

\section{MUCUS SECRETION}

In the normal human airway, mucus is produced and secreted by "mucous" or "goblet" cells. The submucosal glands in the larger airways also contribute to mucus production. Gel-forming mucins are synthesized and stored in a condensed form as large, covalent disulfide-linked oligomers and multimers in cytoplasmic 
vesicles at the apical surface of the goblet cell. Numerous inflammatory and humoral mediators have been shown to stimulate mucin secretion including cholinergic agonists, lipid mediators, oxidants, cytokines, neuropeptides, ATP and UTP, bacterial products, neutrophil elastase, and inhaled pollutants (9). Mucin exocytosis is a complex process controlled by a key regulatory molecule, myristoylated alanine-rich $\mathrm{C}$ kinase substrate (MARCKS), which is bound to the cytoplasmic surface of the plasma membrane in the constitutive state. MARCKS was shown to be essential for mucin release in vitro (10) and in vivo in a mouse model of allergic airway inflammation (11). When phosphorylated by activated protein kinase C, MARCKS translocates from the plasma membrane to the cytoplasm, where subsequent dephosphorylation by protein phosphatase $2 \mathrm{~A}$ restores its membrane-binding capability (10). MARCKS is targeted to bind to the membranes of intracellular mucin granules through interactions with the chaperones, heat shock protein 70 , and cysteine string protein (12). Binding to MARCKS facilitates recruitment of mucin granules to actin, and transport to the apical surface is thus mediated by the contractile cytoskeleton. Docking and fusion of the mucin granules with the plasma membrane are the final steps in exocytosis and are mediated by soluble N-ethylmaleimide sensitive factor attachment receptor (SNARE) proteins that are present on the secretory vesicles (v-SNARE) and their target membranes (t-SNARE). The v- and t-SNAREs interact, in a process that requires the accessory molecules Munc-13 and Munc-18, to form a core complex that brings together the opposing membranes, allowing fusion to occur and releasing mucin into the airway lumen (13). Before release, the densely packed, polyanionic mucin molecules are bound together by high intragranular concentrations of $\mathrm{Ca}^{2+}$. Upon exocytosis, progressive dilution of $\mathrm{Ca}^{2+}$ occurs and the resulting electrostatic repelling forces, combined with water uptake, allow rapid expansion of mucin into the airway (14) (Figure 1).

\section{MUCUS PRODUCTION IN AIRWAY INFLAMMATION}

Goblet cells have many mucin granules, each 1 to $2 \mu \mathrm{m}$ in diameter, that typically occupy more than $75 \%$ of their cytoplasmic volume. They are found throughout the glandular and surface airway epithelia and can be detected histochemically using alcian blue (AB) and periodic acid Schiff's (PAS) stains (15). Submucosal glands, which contain a mixture of goblet cells and serous cells, are distributed throughout the cartilaginous airways in humans, but in mice are limited to the laryngeal region of the trachea. They contribute to mucus secretion but are also an important source of antimicrobial peptides (16). In the small airways of humans and in all intrapulmonary airways in mice, there are very few goblet cells under basal conditions. In mice, for example, ciliated cells $(\sim 40 \%)$ and nonciliated cells $(\sim 60 \%)$, which are mostly Clara cells, account for the vast majority of airway epithelial cells (17). Although traditionally mucus-producing goblet cells have been defined by their aforementioned histochemical staining properties, these stains are relatively insensitive for the detection of mucins. In fact, recent studies indicate that mucus is also secreted by nongoblet cells in the airways. Mice deficient in the exocytic priming protein, Munc 13-2, were shown to accumulate enough Muc5b in airway Clara cells to stain positively with $\mathrm{AB}$ and PAS (18). Furthermore, Muc5b was detected in smaller quantities in the Clara cells of wild-type mice. These data suggest that Clara cells produce mucins at baseline, which are secreted so rapidly by a Munc 13-2-dependent exocytic pathway, that insufficient mucin accumulates in the cell to be detected by conventional histochemical staining techniques. While it is likely that Clara cells contribute

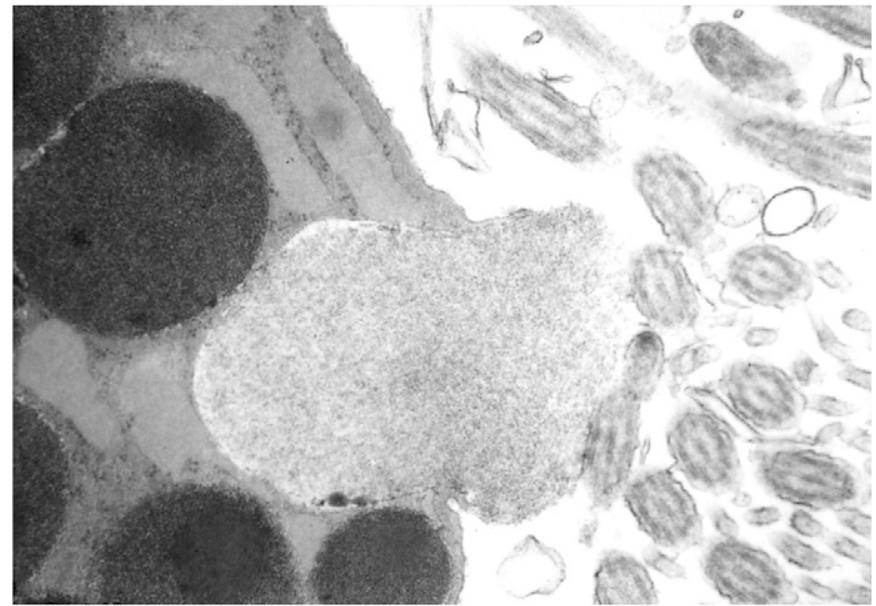

Figure 1. Apical surface of a goblet cell releasing mucin. Electron micrograph of a murine goblet cell. A mucin-containing vesicle has fused to the plasma membrane of the apical airway surface. Note the electron-dense, dark granules that become flocculent and less dense as mucin extrusion occurs and the mucin becomes hydrated. Crosssections of cilia in the airway lumen are from adjacent ciliated cells.

a fraction of the total amount of mucins secreted, it is now clear that gel-forming mucin production is not strictly limited to goblet cells and submucosal glands.

During airway inflammation, the number of goblet cells within the airway epithelium and the amount of mucin produced are significantly increased. Extreme pathological manifestations of these changes have been well described in lung biopsies of individuals with severe asthma and in autopsy specimens from patients with fatal asthma, where obstructing plugs of mucus and cellular debris have been identified in the small and medium sized airways (19). While less than 5\% of airway epithelial cells are goblet cells in healthy individuals, in fatal asthma 20 to $25 \%$ of airway epithelial cells have this phenotype (20). Morphometric analysis of lung sections at autopsy from patients with fatal asthma demonstrated a 20 -fold increase in goblets cells in the peripheral airways when compared with those from control subjects without asthma (21). Furthermore, the amount of intralumenal mucus was markedly increased in fatal asthma and correlated significantly with the number of goblet cells in the airway epithelium.

There is also evidence of mucus hypersecretion and increased goblet cell number in patients with mild to moderate asthma. Endobronchial biopsies from patients with mild to moderate asthma showed a 2-fold increase in goblet cells compared with normal control subjects (22). Goblet cell mucin stores in the airway epithelium were 3-fold higher in the subjects with asthma, and this finding was accounted for by increased goblet cell number rather than goblet cell hypertrophy. While the number of goblet cells in airway biopsies of individuals with mild to moderate asthma was comparable, induced sputum samples showed that those with moderate disease had three times more secreted mucin than those with mild asthma. Goblet cells in the airway epithelium at autopsy were demonstrated to be 30 -fold higher in patients with fatal asthma than those with asthma who died of other causes (21). Thus, mucus hypersecretion related to increased goblet cell number appears to be associated with disease severity in asthma. In the most severe cases of asthma these effects can be dramatic, and pathologic evidence suggests that mucus plugging may be the cause of death in fatal asthma. 


\section{MUCUS METAPLASIA}

The increase in goblet cell numbers in the respiratory epithelium during airway inflammation has been described both as mucous metaplasia and as goblet cell hyperplasia. Metaplasia implies a change in cell phenotype, while hyperplasia suggests cell proliferation as the mechanism for the increase in goblet cell numbers. In human airways, a detailed analysis of the epithelial transition to a mucus-secreting phenotype has not been undertaken. In a murine model of asthma, there was a dramatic increase in goblet cell number after sensitization and allergen challenge, while the number of epithelial cells per unit surface area of the basal lamina remained constant (23). Furthermore, this change was accompanied by a $75 \%$ decrease in Clara cells and a $25 \%$ decrease in ciliated cells, suggesting that Clara and ciliated cells can convert to goblet cells and that metaplasia is the dominant mechanism mediating the expansion in goblet cell numbers. In the airways of smokers, goblet cells are increased compared with the airways of nonsmokers. This occurs at sites normally occupied by Clara cells, suggesting a transition of Clara to goblet cells in human disease (24). Ciliated cells have also been observed to transition to goblet cells in murine models of chronic viral infection and in COPD (25). Therefore, it is likely that the goblet cell, which was defined histologically, is of variable lineage. In both murine and human airway epithelia, mucus metaplasia appears to serve a critical host protective function in response to many forms of airway damage. Mucus metaplasia leads to an increase in mucus secretions, thus increasing clearance of dead cells and pathogens in an attempt to restore a healthy respiratory tract. When the damaging stimulus is gone, goblet cells undergo apoptosis and are replaced by the normal epithelium consisting mostly of Clara and ciliated cells. In chronic airway diseases, these danger signals persist, promoting continued mucus metaplasia, mucous gland hypertrophy, and mucus hypersecretion.

\section{MECHANISMS OF MUCUS METAPLASIA}

\section{Th2 Cytokines}

Mucus hypersecretion is induced by airway inflammation and is caused by a variety of different stimuli associated with different cytokine expression profiles. Asthma is believed to be caused, in part, by allergen-specific $\mathrm{T}$ helper 2 (Th2) lymphocytes that produce the cytokines IL-4, IL-5, IL-9, IL-10, and IL-13 (26). Many studies into the mechanisms of mucous metaplasia have thus focused on mouse models of Th2 cell-mediated airway inflammation. Chronic overexpression of individual Th2 cytokines has been achieved using lung-specific promoters. Overexpresser transgenic mice with the Clara cell $10-\mathrm{kD}$ (CC10) promoter driving the Th2 cytokines IL-4, IL-5, IL-9, or IL-13 exhibited the characteristic features of allergic airway inflammation, including eosinophilia, mast cell activation, and mucus overproduction (27-30). Together these studies indicated that allergic airway inflammation in various models led to mucous metaplasia.

A number of studies addressed which particular Th2 inflammatory cells and mediators resulted in mucous metaplasia. Initial studies in antigen-challenged animals suggested that both IL-4 and eosinophils correlated with mucus hypersecretion (3133). However, mucus hypersecretion and goblet cell metaplasia were still readily inducible, after antigen challenge, in mice genetically deficient in eosinophils $(34,35)$. Furthermore, Th2 cells from IL-4 $4^{-1-}$ mice could induce mucus production as effectively as wild-type Th2 cells (36). Thus, neither IL-4 nor eosinophils are essential for induction of mucous metaplasia in Th2-mediated airway inflammation.
IL-4 and IL-13 share a common receptor subunit: IL-4R $\alpha 1$. Blockade of IL-4/IL-13 signaling, through knockout of IL-4R $\alpha 1$, resulted in failure of IL-13 or Th2 cells to induce mucous metaplasia (37-39). In the absence of IL-13, Th2 cells that produced IL-4 and IL-5 could no longer stimulate mucus production $(40,41)$. Furthermore, mucus hypersecretion in transgenic mice with lung-specific overexpression of IL-4, IL-5, or IL-9 was found to be IL-13 dependent (41-43). For example, mucous metaplasia was abolished in transgenic mice overexpressing IL-9 when IL-13 signaling was inhibited through STAT6 deletion. Ablation of lymphocytes, eosinophils, and mast cells in transgenic IL-9 mice did not reduce IL-13 levels or mucous metaplasia, and in situ hybridization indicated that airway epithelial cells were the source of IL-13 (44). These studies showed that IL-13 is necessary for Th2-mediated airway inflammation in mice. Furthermore, IL-13 is highly potent and very low levels can effectively promote mucous metaplasia (41).

IL-13 appears to act via direct effects on airway epithelial cells. STAT6 ${ }^{-1-}$ mice with transgenic overexpression of IL-13 did not develop mucus overproduction, but mucin gene expression and mucous metaplasia were restored after selective reconstitution of STAT6 in airway epithelial cells (45). These findings were extended to the allergen-induced model of airway inflammation, where Th2 cells failed to induce the mucous phenotype in mice with conditional deletion of IL-4R $\alpha$ in Clara cells, and in bone marrow chimeras where the host mice were IL-4R $\alpha 1^{-1-}(41,46)$. Thus, IL-13 is essential for Th2 cellinduced mucous metaplasia through direct effects on the airway epithelium. Downstream epithelial cell signaling events are mediated by STAT6-dependent de novo protein synthesis, resulting in activation of p38 mitogen-activated protein kinase, which appears to be essential for IL-13-induced mucous metaplasia (47). Studies in airway epithelial cell cultures using specific inhibitors also suggest that phosphatidylinositol 3 kinase (PI3K) is required for IL-13-induced mucin gene expression and mucus staining (48).

In humans, it is not clear whether IL-13 has the same exclusive role in inducing mucus production that it has in mouse models. Human airway epithelial cells cultured in the presence of IL-13 develop a mucous phenotype over a period of days. However, IL-4 can also induce mucin gene expression and mucus staining in these cells $(48,49)$, although the concentrations of IL-4 used in these studies are likely supraphysiologic, which may explain the differences observed between the murine in vivo and the human in vitro systems.

Although IL-13 is synonymous with an adaptive Th2-mediated immune response, recent work suggests the role of IL-13 in mucous metaplasia is not limited to allergic inflammation. In Sendai virus-infected mice, mucous metaplasia was induced by IL-13 produced by macrophages, which were stimulated by invariant natural killer T cells. This innate immune axis may also be activated in the lungs of humans with asthma and COPD (50).

\section{Epidermal Growth Factor Receptor}

Epidermal growth factor receptor (EGFR) has critical functions in growth, differentiation, and repair of airway epithelial cells $(51,52)$. Human airway epithelial cells stimulated with the EGFR ligands, transforming growth factor- $\alpha$ (TGF- $\alpha)$ and EGF, developed a mucous phenotype (53). Intratracheal administration of these ligands after TNF- $\alpha$-induced up-regulation of airway epithelial cell EGFR in rats resulted in mucous metaplasia. Pharmacologic inhibition of EGFR tyrosine kinase activity abolished the effects of EGFR ligands on mucus production both in vivo and in vitro. Subsequent studies showed that EGFR activation is required for inducing mucous metaplasia in animal models and for up-regulation of mucin expression in human 
airway epithelial cells in response to allergens, viruses, neutrophils, and cigarette smoke $(25,53-56)$. EGFR expression was also shown to be up-regulated in the airway epithelium of humans with asthma (57, 58), COPD (59), and CF (60). Thus, EGFR is another necessary signal for mucous metaplasia.

\section{EGFR and IL-13 Control Transition to Goblet Cell}

A two-step model showing that goblet cell transition requires both EGFR and IL-13 was demonstrated in studies using a mouse model of chronic mucous metaplasia after Sendai virus infection (25). EGFR activation of ciliated epithelial cells led to anti-apoptotic effects and ciliated cell hyperplasia. IL-13 treatment resulted in cells that transiently shared characteristics of both ciliated and goblet cells, followed by the later expansion of mature goblet cells. This work suggests that EGFR activation inhibits ciliated cell apoptosis and primes the cell to respond to a second signal, IL-13, which induces transition from a ciliated to goblet cell phenotype. IL-13 not only induces Muc5ac gene expression leading to mucin synthesis, a defining characteristic of the goblet cell phenotype, but also induces other genes, some of which are important for goblet cell function, including the genes for the calcium activated chloride channel and the trefoil factor family (61-63) (Figure 2).

A number of transcription factors that are important in lung development have been identified in the airway epithelium and have been shown to play key roles in mucous metaplasia. The forkhead box transcription factor, FOXA2, regulates genes that are involved in lung maturation and epithelial cell differentiation. Targeted deletion of Foxa2 in the airway epithelium of mice results in spontaneous mucous metaplasia, and in vitro reporter assays show that FOXA2 inhibits muc5ac gene expression (64). Allergen challenge or transgenic overexpression of IL-4 or IL-13 in mice resulted in pulmonary inflammation and goblet cell metaplasia, which was associated with significant inhibition of Foxa2 expression in the airway epithelium $(64,65)$.
FOXA2 expression has also been demonstrated in normal human airways, but was absent in mucous cells of patients with bronchiectasis and cystic fibrosis. Thus, FOXA2 is required for maintenance of normal differentiation of the airway epithelium and inhibition of FOXA2 appears to be an important early step in the initiation of mucous metaplasia.

Thyroid transcription factor 1 (TTF-1) plays a critical role in peripheral lung morphogenesis and is an important regulator of genes involved in many biological functions in the lung, including host defense, fluid balance, surfactant homeostasis, lung vasculogenesis, and epithelial cell differentiation (66). Sam pointed domain-containing ETS transcription factor (SPDEF), an epithelial specific transcription factor that is markedly induced by a phophorylation mutant of TTF-1, was shown to be constitutively expressed in proximal airway epithelial cells and submucosal glands in the adult mouse lung (67). Transgenic overexpression of SPDEF in the murine airway epithelium caused spontaneous mucous metaplasia. Interestingly, SPDEF appeared to interact with TTF-1 to have a synergistic effect on the promoters of a number of genes but had no direct effect on the Muc5AC gene promoter. SPDEF overexpression did, however, result in down-regulation of FoxA2 expression, placing it upstream of FoxaA2 in goblet cell differentiation. Furthermore, allergen and IL-13 exposure caused mucous metaplasia and SPDEF induction that was Stat6 dependent. These findings support a role for SPDEF in allergen-mediated mucous metaplasia, but it is unclear whether SPDEF is required for goblet cell differentiation in the lung. (Note Added in Proof [Dec 2009]: SPDEF has now been shown to be both necessary and sufficient for induction of a transcriptional program that results in goblet cell differentiation [88]).

$\gamma$-Aminobutyric acid (GABA) has also been identified as an important regulator of goblet cell metaplasia. The $\mathrm{GABA}_{\mathrm{A}}$ receptor $\left(G_{A B A} R\right)$ is a pentameric chloride channel that mediates inhibitory signals in the brain (68). GABA $A_{A} R$ and

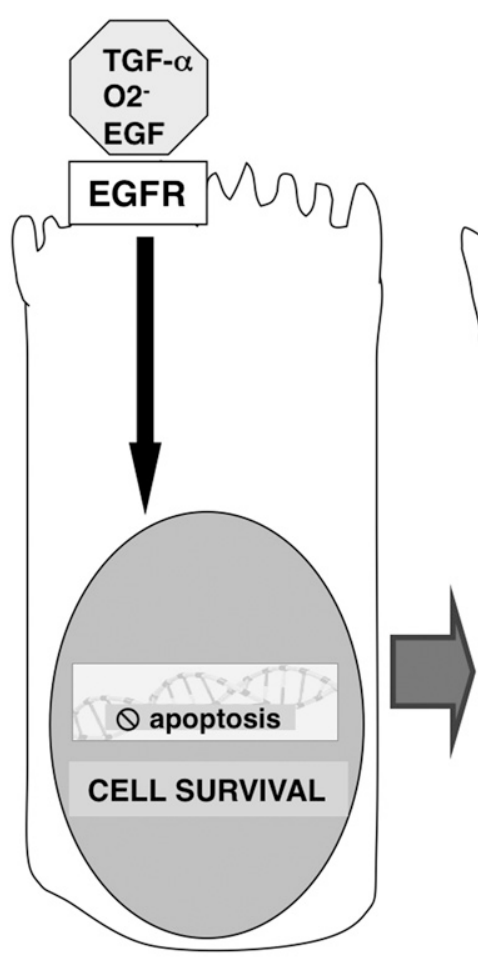

Signal 1

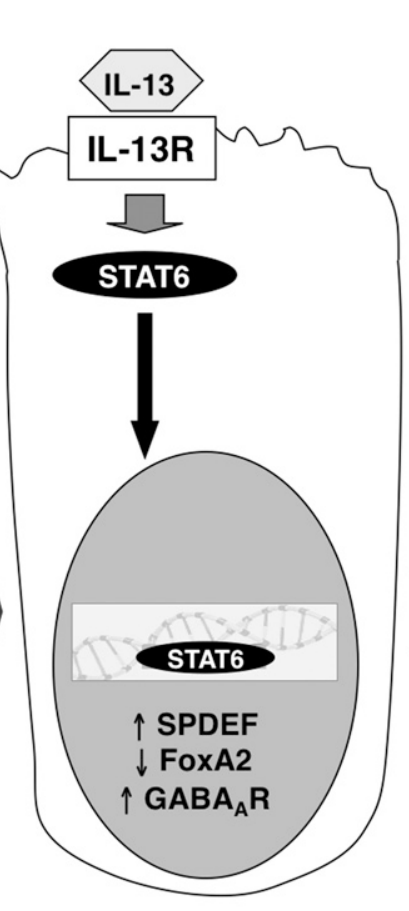

Signal 2

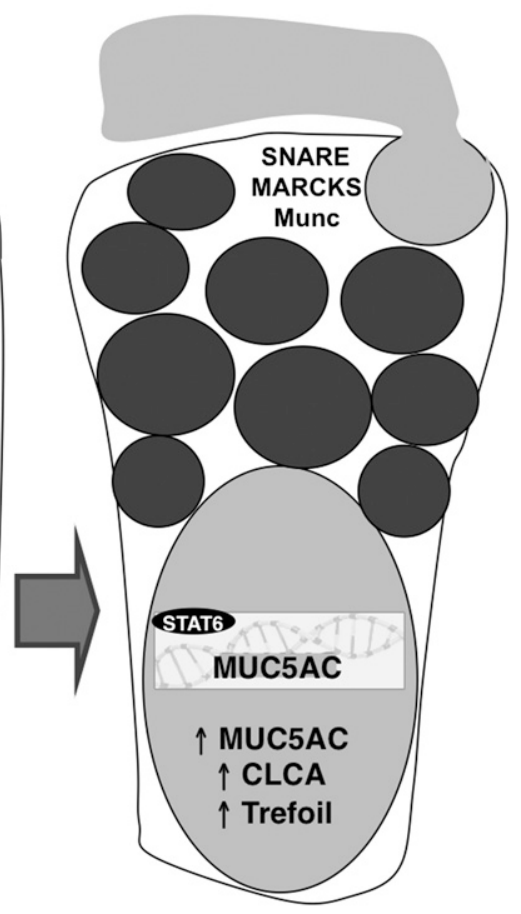

Goblet Cell
Figure 2. Goblet cell differentiation requires two signals. The hypothesis: Signal 1 activates the epidermal growth factor receptor (EGFR) on the ciliated cells, leading to inhibition of epithelial cell apoptosis. Epithelial cells that survive have the potential to become goblet cells if provided with Signal 2, IL-13 binding to its receptor. Upon IL-13R and Stat 6 activation, epithelial cells show an increase in SPDEF and reduced FoxA2 expression. These effects are IL-13 dependent, yet their blockade inhibits goblet cell induction, placing them early in goblet cell transition. GABAA-R responsiveness is required for goblet cell metaplasia and is induced by IL-13. After IL-13 activation, cells lose the features of epithelial cells from which they arose and become goblet cells that produce mucins and other factors necessary for secretory functions. 
GABA synthetic enzymes were also shown to be expressed in airway epithelial cells (69). In vitro studies demonstrated that GABA enhanced airway epithelial cell proliferation and increased mucin production and secretion. $\mathrm{GABA}_{\mathrm{A}} \mathrm{R}$ antagonists significantly inhibited goblet cell metaplasia in antigen-challenged mice, despite having no effect on the influx of inflammatory cells or IL-13 levels. Furthermore, IL-13 induced GABA ${ }_{\mathrm{A}} \mathrm{R}$ expression in airway epithelial cells both in vitro and in vivo. Thus, the airway epithelial GABAergic system promotes mucous metaplasia by effects that are downstream of IL-13.

Calcium-activated chloride channels (CLCAs) also appear to control airway mucus. CLCA proteins are no longer thought to function as chloride channels, but may enhance calcium signaling and are secreted into the airway and cleaved into peptides that may signal the epithelium to induce mucus $(70,71)$. These effects of CLCA are downstream of Th2 cytokines and are Stat6 dependent. There may be overlapping functions of CLCA proteins explaining why $\mathrm{ClCa} 3$-deficient mice were still able to produce mucus in the airways comparable to wild-type mice, yet siRNA blockade, which may have inhibited expression of multiple orthologous CLCA genes, led to inhibition of mucus in a mouse model of allergic airway disease (70). CLCA1 expression is increased in human inflammatory airway diseases and is associated with mucus production. Further investigations will define where in the signaling cascade, downstream of Stat6, CLCA proteins impact on mucus production.

IL-13 does not appear to directly regulate Muc5AC gene expression since the consensus motif for STAT6 was not identified in the Muc5AC 5' flanking region (72). However, IL-13 was shown to induce Muc5AC expression via a mechanism requiring a secondary TGF- $\beta 2 / \mathrm{SMAD}$-mediated signal in airway epithelial cell cultures (73). Furthermore, mutation of the Smad4 and hypoxia-inducible factor-1 (HIF-1) consensus motifs were shown to impair Muc5AC promoter function in vitro (72). HIF-1 is known to contain a conserved STAT6 motif in its promoter, and binding of HIF-1 to the Muc5AC promoter is induced by IL-13 and EGF stimulation. These studies highlight a complex process by which goblet cell differentiation occurs. An inflammatory stimulus causes EGFR activation, promoting epithelial cell survival and facilitating a response to IL-13, which in turn controls multiple steps in the differentiation and function of goblet cells.

\section{GOBLET CELL INHIBITION}

Mucous metaplasia does not occur in all immune responses, particularly those rich in IFN- $\gamma$. Th1 cell-induced airway inflammation did not stimulate mucous metaplasia (36). It was initially believed that Th1 cells did not produce the factors necessary to induce this effect. Yet, when IFN- $\gamma$ effects were blocked in Th1-induced airway inflammation, mucus was readily induced, indicating that all of the necessary signals for mucus induction were provided in the respiratory tract in Th1 inflammation (74). The ability of Th1 cells to stimulate mucous metaplasia was due to IL-13 production but could only be observed when IFN- $\gamma$ responses were blocked. IFN- $\gamma$ inhibits mucous cell transition, even in the presence of high levels of Th2 cytokines (L. Cohn, unpublished data). Thus, IFN- $\gamma$ may inhibit airway epithelial mucus by blocking steps required for IL-13 to act, such as inhibiting EGFR actions to promote cell survival. Alternatively, IFN- $\gamma$ may act by inhibiting downstream effects of IL-13.

The molecular mechanisms by which IFN- $\gamma$ inhibits mucus are still being defined. In cultured human airway epithelial cells, IFN- $\gamma$ was shown to inhibit IL-4-induced STAT6 phosphorylation and to reduce the expression of IL-4 target genes (75).
Furthermore, IFN- $\gamma$ also induced expression of suppressor of cytokine signaling-1 and IL-13R $\alpha 2$, inhibitors of IL-4/IL-13 signaling, as well as increasing the decay of IL-4 target gene mRNA. Thus, IFN- $\gamma$ may inhibit Th2-induced responses in epithelial cells through a number of pathways. IFN- $\gamma$ also promotes resolution of allergen-induced mucous metaplasia by stimulating airway epithelial apoptosis via Bax- and caspase-dependent mechanisms (76). IFN- $\gamma$-induced cell death involves STAT1dependent translocation of Bax to the endoplasmic reticulum (77). IFN- $\gamma$ thus appears to both inhibit development of goblet cells and accelerate their loss.

\section{THERAPIES FOR EXCESS MUCUS PRODUCTION}

Under normal circumstances mucous metaplasia serves a crucial function in host defense and repair by increasing elimination of dead and dying cells and pathogens in the airways. However, in diseases with mucus hypersecretion, excess mucus becomes part of the pathophysiology. Reducing mucus should improve symptoms and airway obstruction. The goals for mucus control should be (1) to reduce but not eliminate lower respiratory tract mucus secretions, (2) to maintain a reasonable mucus viscosity to facilitate effective clearance, and (3) to act locally and maintain normal mucous secretions at other mucosal surfaces.

\section{Anti-Inflammatory Therapies}

Inhibition of mucus may occur in concert with conventional treatment of chronic airway diseases that are aimed at reducing inflammation. In asthma and COPD, corticosteroids are central to the treatment of acute exacerbations and in maintaining chronic disease control. In CF and COPD, treatment of intercurrent infections is a mainstay of therapy. Since mucus hyperproduction is a result of inflammatory stimuli, these treatments are often effective in reducing mucus production in exacerbations. Yet, reducing inflammation by these methods may take days, as mucous glands and goblet cells take time to involute, thus delaying the response. Furthermore, the inflammatory response in COPD may not be inhibited by corticosteroids (78). Other anti-inflammatory drugs, such as leukotriene blockers, phosphodiesterase inhibitors, NSAIDS, and macrolides may augment anti-inflammatory effects and translate into improved mucus control.

Novel anti-inflammatory therapies with specific targets that impact on mucus are currently in development. Drugs that block IL-13 or both IL-4 and IL-13 are being tested in asthma and have shown efficacy (79). Specific data on the effects on mucus, though, are not available. EGFR small molecule inhibitors such as erlotinib or gefitinib, or monoclonal antibodies such as cetuximab, are approved for use in malignancies. Their utility in mucus control in asthma and COPD has been hypothesized but not tested (51). Small molecule inhibitors of pathways downstream of EGFR and IL-13, including inhibitors of MEK, p38 mitogen-activated protein kinase, and PI3K are other potential pathways whereby specific blockade might impact on mucus hypersecretion. Inhaled IFN- $\gamma$ has been tested in subjects with asthma over a short period of exposure (80), but never tested for its long-term efficacy in asthma or mucus hypersecretion.

Chronic administration of $\beta$-blockers in allergen-challenged mice has recently been shown to attenuate mucous metaplasia $(81,82)$. $\beta$-adrenoceptor inverse agonists are a subset of $\beta$-blockers that not only inhibit agonist-induced signaling, but also inhibit signaling produced by constitutively active receptors. In a mouse model of allergic asthma, $\beta$-adrenoceptor null mice or wild-type mice that received chronic administration of $\beta$-adrenoceptor inverse agonists exhibited reduced airway 
inflammation and mucous metaplasia. These studies suggest that signaling via constitutively active, unligated $\beta$-adrenoceptors contributes significantly to mucous metaplasia. $\beta$-blockers are currently contraindicated in asthma because their acute administration may cause increased airway resistance $(83,84)$, but a small, open-label pilot study in subjects with mild asthma showed that escalating doses of nadolol were well tolerated and treatment resulted in a dose-dependent improvement in airway hyperresponsiveness, as assessed by $\mathrm{PC}_{20}$ to methacholine (85).

\section{Bronchodilators}

Other conventional therapies in chronic airway diseases include bronchodilators, anticholinergic and $\beta$-agonist drugs, and theophylline, which may enhance mucus expulsion through bronchodilatory effects or increased mucociliary function $(86,87)$. Weighing the importance of $\beta$-agonist drugs for their bronchodilatory functions and their less studied but likely positive effects on mucus clearance versus their potential negative role in inflammation highlights the complexities of treating these life-threatening respiratory conditions.

\section{Blockade of Mucus Secretion}

Inhibition of mucus secretion is another alternative to limiting mucus. Inhibiting MARCKS, SNAREs, Munc-13, or Munc-18 are possible molecular targets. Two concerns surround inhibition of mucus secretion. If mucus secretion is blocked, but mucus production is ongoing, it is unclear what will happen to the goblet cells. The effects could include goblet cell swelling and airway obstruction. Furthermore, numerous cells in the respiratory tract that have secretory functions share components of the mucous secretory apparatus. Thus, if blockade of mucus secretion can be achieved, it could alter other essential secretory functions in the respiratory tract. As inhibitors of these pathways are developed, their effects in vivo will be revealed.

\section{CONCLUSIONS}

Over the past decade there have been significant advances in our understanding of the cellular and molecular mechanisms that regulate airway mucus. Investigators can now take advantage of these insights to devise new strategies to block mucus. More effective blockade of mucus early in acute exacerbations of asthma, COPD, and CF will reduce hospitalizations, morbidity and mortality, and long-term inhibition of mucus may lessen the burden of these diseases. Therapies in development, such as new anti-inflammatory agents, might have considerable efficacy in the inhibition of mucus, yet this has not been an endpoint in such studies. Given the consensus that mucous hypersecretion contributes significantly to the pathophysiology of chronic airway diseases, inhibition of mucus should be a therapeutic focus in the future.

Conflict of Interest Statement: L.C. has served on the advisory board (Data Safety Monitoring Board) for MannKind Corporation $(\$ 10,000-\$ 50,000)$. D.R.C. does not have a financial relationship with a commercial entity that has an interest in the subject of this manuscript.

Acknowledgments: The authors thank Robert Homer for helpful discussion and providing the electron micrograph and Susan Ardito for administrative support.

\section{References}

1. Nutton V. Ancient medicine. New York: Routledge; 2004. pp. 53-71.

2. Osler W. Modern medicine: its theory and practice. New York: Lea \& Febiger; 1914. p. 905.

3. Voynow JA, Gendler SJ, Rose MC. Regulation of mucin genes in chronic inflammatory airway diseases. Am J Respir Cell Mol Biol 2006;34:661-665.
4. Rose MC, Voynow JA. Respiratory tract mucin genes and mucin glycoproteins in health and disease. Physiol Rev 2006;86:245-278.

5. Carraway KL, Perez A, Idris N, Jepson S, Arango M, Komatsu M, Haq B, Price-Schiavi SA, Zhang J, Carraway CA. Muc4/sialomucin complex, the intramembrane erbb2 ligand, in cancer and epithelia: to protect and to survive. Prog Nucleic Acid Res Mol Biol 2002;71: $149-185$.

6. Li Y, Bharti A, Chen D, Gong J, Kufe D. Interaction of glycogen synthase kinase 3beta with the $\mathrm{df} 3 /$ muc1 carcinoma-associated antigen and beta-catenin. Mol Cell Biol 1998;18:7216-7224.

7. Moniaux N, Escande F, Batra SK, Porchet N, Laine A, Aubert JP. Alternative splicing generates a family of putative secreted and membrane-associated muc4 mucins. Eur J Biochem 2000;267:45364544.

8. Perez-Vilar J. Mucin granule intraluminal organization. Am J Respir Cell Mol Biol 2007;36:183-190.

9. Martin LD, Rochelle LG, Fischer BM, Krunkosky TM, Adler KB. Airway epithelium as an effector of inflammation: molecular regulation of secondary mediators. Eur Respir J 1997;10:2139-2146.

10. Li Y, Martin LD, Spizz G, Adler KB. MARCKS protein is a key molecule regulating mucin secretion by human airway epithelial cells in vitro. J Biol Chem 2001;276:40982-40990.

11. Singer M, Martin LD, Vargaftig BB, Park J, Gruber AD, Li Y, Adler KB. A MARCKS-related peptide blocks mucus hypersecretion in a mouse model of asthma. Nat Med 2004;10:193-196.

12. Park J, Fang S, Crews AL, Lin KW, Adler KB. MARCKS regulation of mucin secretion by airway epithelium in vitro: interaction with chaperones. Am J Respir Cell Mol Biol 2008;39:68-76.

13. Hong W. SNAREs and traffic. Biochim Biophys Acta 2005;1744: 493-517.

14. Rogers DF. The airway goblet cell. Int J Biochem Cell Biol 2003;35:1-6.

15. Evans CM, Koo JS. Airway mucus: The good, the bad, the sticky. Pharmacol Ther 2008

16. Wine JJ, Joo NS. Submucosal glands and airway defense. Proc Am Thorac Soc 2004;1:47-53.

17. Evans CM, Williams OW, Tuvim MJ, Nigam R, Mixides GP, Blackburn MR, DeMayo FJ, Burns AR, Smith C, Reynolds SD, et al. Mucin is produced by Clara cells in the proximal airways of antigen-challenged mice. Am J Respir Cell Mol Biol 2004;31:382-394.

18. Zhu Y, Ehre C, Abdullah LH, Sheehan JK, Roy M, Evans CM, Dickey BF, Davis CW. Munc13-2-1- baseline secretion defect reveals source of oligomeric mucins in mouse airways. J Physiol 2008;586: 1977-1992.

19. Kuyper LM, Pare PD, Hogg JC, Lambert RK, Ionescu D, Woods R, Bai TR. Characterization of airway plugging in fatal asthma. Am J Med 2003;115:6-11.

20. Shimura S, Andoh Y, Haraguchi M, Shirato K. Continuity of airway goblet cells and intraluminal mucus in the airways of patients with bronchial asthma. Eur Respir J 1996;9:1395-1401.

21. Aikawa T, Shimura S, Sasaki H, Ebina M, Takishima T. Marked goblet cell hyperplasia with mucus accumulation in the airways of patients who died of severe acute asthma attack. Chest 1992;101:916-921.

22. Ordonez CL, Khashayar R, Wong HH, Ferrando R, Wu R, Hyde DM, Hotchkiss JA, Zhang Y, Novikov A, Dolganov G, et al. Mild and moderate asthma is associated with airway goblet cell hyperplasia and abnormalities in mucin gene expression. Am J Respir Crit Care Med 2001;163:517-523.

23. Reader JR, Tepper JS, Schelegle ES, Aldrich MC, Putney LF, Pfeiffer JW, Hyde DM. Pathogenesis of mucous cell metaplasia in a murine asthma model. Am J Pathol 2003;162:2069-2078.

24. Lumsden AB, McLean A, Lamb D. Goblet and Clara cells of human distal airways: Evidence for smoking induced changes in their numbers. Thorax 1984;39:844-849.

25. Tyner JW, Kim EY, Ide K, Pelletier MR, Roswit WT, Morton JD, Bataile JT, Patel AC, Patterson A, Castro M, et al. Blocking airway mucous cell metaplasia by inhibiting EGFR anti-apoptosis and IL-13 transdifferentiation signals. J Clin Invest 2006;116:309-321.

26. Cohn L, Elias JA, Chupp GL. Asthma: mechanisms of disease persistence and progression. Annu Rev Immunol 2004;22:789-815.

27. Lee JJ, McGarry MP, Farmer SC, Denzler KL, Larson KA, Carrigan PE, Brenneise IE, Horton MA, Haczku A, Gelfand EW, et al. Interleukin-5 expression in the lung epithelium of transgenic mice leads to pulmonary changes pathognomonic of asthma. J Exp Med 1997; 185:2143-2156.

28. Rankin JA, Picarella DE, Geba GP, Temann A, Prasad B, DiCosimo B, Tarallo A, Stripp B, Whitsett J, Flavell RA. Phenotypic and physi- 
ologic characterization of transgenic mice expressing interleukin 4 in the lung: Lymphocytic and eosinophilic inflammation without airway hyperreactivity. Proc Natl Acad Sci USA 1996;93:7821-7825.

29. Temann UA, Prasad B, Gallup MW, Basbaum C, Ho SB, Flavell RA, Rankin JA. A novel role for murine IL-4 in vivo: induction of muc5ac gene expression and mucin hypersecretion. Am J Respir Cell Mol Biol 1997;16:471-478.

30. Zhu Z, Homer R, Wang Z, Chen Q, Geba G, Wang J, Zhang Y, Elias J. Transgenic expression of IL-13 in murine lung causes airway inflammation, mucus hypersecretion, subendothelial fibrosis, eotaxin production and airways hyperresponsiveness to methacholine. J Clin Invest 1999;103:779-788.

31. Gavett SH, O'Hearn DJ, Karp CL, Patel EA, Schofield BH, Finkelman FD, Wills-Karp M. Interleukin-4 receptor blockade prevents airway responses induced by antigen challenge in mice. Am J Physiol 1997; 272:L253-L261.

32. Henderson WR Jr, Lewis DB, Albert RK, Zhang Y, Lamm WJ, Chiang GK, Jones F, Eriksen P, Tien YT, Jonas M, et al. The importance of leukotrienes in airway inflammation in a mouse model of asthma. J Exp Med 1996;184:1483-1494.

33. Savoie C, Plant M, Zwikker M, van Staden CJ, Boulet L, Chan CC, Rodger IW, Pon DJ. Effect of dexamethasone on antigen-induced high molecular weight glycoconjugate secretion in allergic guinea pigs. Am J Respir Cell Mol Biol 1995;13:133-143.

34. Humbles AA, Lloyd CM, McMillan SJ, Friend DS, Xanthou G, McKenna EE, Ghiran S, Gerard NP, Yu C, Orkin SH, et al. A critical role for eosinophils in allergic airways remodeling. Science 2004;305:1776-1779.

35. Lee JJ, Dimina D, Macias MP, Ochkur SI, McGarry MP, O'Neill KR, Protheroe C, Pero R, Nguyen T, Cormier SA, et al. Defining a link with asthma in mice congenitally deficient in eosinophils. Science 2004:305:1773-1776.

36. Cohn L, Homer RJ, Marinov A, Rankin J, Bottomly K. Induction of airway mucus production by $\mathrm{T}$ helper 2 (Th2) cells: a critical role for interleukin 4 in cell recruitment but not mucus production. J Exp Med 1997;186:1737-1747.

37. Cohn L, Homer RJ, MacLeod H, Mohrs M, Brombacher F, Bottomly K. Th2-induced airway mucus production is dependent on IL-4R-alpha, but not on eosinophils. J Immunol 1999;162:6178-6183.

38. Grunig G, Warnock M, Wakil AE, Venkayya R, Brombacher F, Rennick DM, Sheppard D, Mohrs M, Donaldson DD, Locksley RM, et al. Requirement for IL-13 independently of IL-4 in experimental asthma. Science 1998;282:2261-2263.

39. Wills-Karp M, Luyimbazi J, Xu X, Schofield B, Neben TY, Karp CL, Donaldson DD. Interleukin-13: central mediator of allergic asthma. Science 1998;282:2258-2261.

40. Walter DM, McIntire JJ, Berry G, McKenzie AN, Donaldson DD, DeKruyff RH, Umetsu DT. Critical role for IL-13 in the development of allergen-induced airway hyperreactivity. J Immunol 2001;167:46684675.

41. Whittaker L, Niu N, Temann UA, Stoddard A, Flavell RA, Ray A, Homer RJ, Cohn L. Interleukin-13 mediates a fundamental pathway for airway epithelial mucus induced by CD4 T cells and interleukin-9. Am J Respir Cell Mol Biol 2002;27:593-602.

42. Justice JP, Crosby J, Borchers MT, Tomkinson A, Lee JJ, Lee NA. $\mathrm{CD} 4(+) \mathrm{T}$ cell-dependent airway mucus production occurs in response to IL-5 expression in lung. Am J Physiol Lung Cell Mol Physiol 2002;282:L1066-L1074.

43. Temann UA, Ray P, Flavell RA. Pulmonary overexpression of IL-9 induces th 2 cytokine expression, leading to immune pathology. J Clin Invest 2002:109:29-39.

44. Temann UA, Laouar Y, Eynon EE, Homer R, Flavell RA. IL-9 leads to airway inflammation by inducing IL-13 expression in airway epithelial cells. Int Immunol 2007;19:1-10.

45. Kuperman DA, Huang X, Koth LL, Chang GH, Dolganov GM, Zhu Z, Elias JA, Sheppard D, Erle DJ. Direct effects of interleukin-13 on epithelial cells cause airway hyperreactivity and mucus overproduction in asthma. Nat Med 2002;8:885-889.

46. Kuperman DA, Huang X, Nguyenvu L, Holscher C, Brombacher F, Erle DJ. IL-4 receptor signaling in clara cells is required for allergeninduced mucus production. J Immunol 2005;175:3746-3752.

47. Fujisawa T, Ide K, Holtzman MJ, Suda T, Suzuki K, Kuroishi S, Chida $\mathrm{K}$, Nakamura $\mathrm{H}$. Involvement of the p38 mapk pathway in IL-13induced mucous cell metaplasia in mouse tracheal epithelial cells. Respirology 2008;13:191-202.

48. Atherton HC, Jones G, Danahay H. IL-13-induced changes in the goblet cell density of human bronchial epithelial cell cultures: MAP kinase and phosphatidylinositol 3-kinase regulation. Am J Physiol Lung Cell Mol Physiol 2003;285:L730-L739.

49. Dabbagh K, Takeyama K, Lee HM, Ueki IF, Lausier JA, Nadel JA. IL-4 induces mucin gene expression and goblet cell metaplasia in vitro and in vivo. J Immunol 1999;162:6233-6237.

50. Kim EY, Battaile JT, Patel AC, You Y, Agapov E, Grayson MH, Benoit LA, Byers DE, Alevy Y, Tucker J, et al. Persistent activation of an innate immune response translates respiratory viral infection into chronic lung disease. Nat Med 2008;14:633-640.

51. Burgel PR, Nadel JA. Roles of epidermal growth factor receptor activation in epithelial cell repair and mucin production in airway epithelium. Thorax 2004;59:992-996.

52. Hackel PO, Zwick E, Prenzel N, Ullrich A. Epidermal growth factor receptors: critical mediators of multiple receptor pathways. Curr Opin Cell Biol 1999;11:184-189.

53. Takeyama K, Dabbagh K, Lee HM, Agusti C, Lausier JA, Ueki IF, Grattan KM, Nadel JA. Epidermal growth factor system regulates mucin production in airways. Proc Natl Acad Sci USA 1999;96:30813086.

54. Takeyama K, Jung B, Shim JJ, Burgel PR, Dao-Pick T, Ueki IF, Protin U, Kroschel P, Nadel JA. Activation of epidermal growth factor receptors is responsible for mucin synthesis induced by cigarette smoke. Am J Physiol Lung Cell Mol Physiol 2001;280:L165-L172.

55. Burgel PR, Lazarus SC, Tam DC, Ueki IF, Atabai K, Birch M, Nadel JA. Human eosinophils induce mucin production in airway epithelial cells via epidermal growth factor receptor activation. J Immunol 2001; 167:5948-5954.

56. Shim JJ, Dabbagh K, Ueki IF, Dao-Pick T, Burgel PR, Takeyama K, Tam DC, Nadel JA. IL-13 induces mucin production by stimulating epidermal growth factor receptors and by activating neutrophils. Am J Physiol Lung Cell Mol Physiol 2001;280:L134-L140.

57. Amishima M, Munakata M, Nasuhara Y, Sato A, Takahashi T, Homma Y, Kawakami Y. Expression of epidermal growth factor and epidermal growth factor receptor immunoreactivity in the asthmatic human airway. Am J Respir Crit Care Med 1998;157:1907-1912.

58. Takeyama K, Fahy JV, Nadel JA. Relationship of epidermal growth factor receptors to goblet cell production in human bronchi. Am J Respir Crit Care Med 2001;163:511-516.

59. de Boer WI, Hau CM, van Schadewijk A, Stolk J, van Krieken JH, Hiemstra PS. Expression of epidermal growth factors and their receptors in the bronchial epithelium of subjects with chronic obstructive pulmonary disease. Am J Clin Pathol 2006;125:184-192.

60. Voynow JA, Fischer BM, Roberts BC, Proia AD. Basal-like cells constitute the proliferating cell population in cystic fibrosis airways. Am J Respir Crit Care Med 2005;172:1013-1018.

61. Kouznetsova I, Chwieralski CE, Balder R, Hinz M, Braun A, Krug N, Hoffmann W. Induced trefoil factor family 1 expression by transdifferentiating Clara cells in a murine asthma model. Am J Respir Cell Mol Biol 2007;36:286-295.

62. Yasuo M, Fujimoto K, Tanabe T, Yaegashi H, Tsushima K, Takasuna K, Koike T, Yamaya M, Nikaido T. Relationship between calciumactivated chloride channel 1 and muc5ac in goblet cell hyperplasia induced by interleukin-13 in human bronchial epithelial cells. Respiration 2006;73:347-359.

63. Zhen G, Park SW, Nguyenvu LT, Rodriguez MW, Barbeau R, Paquet AC, Erle DJ. IL-13 and epidermal growth factor receptor have critical but distinct roles in epithelial cell mucin production. Am J Respir Cell Mol Biol 2007:36:244-253.

64. Wan H, Kaestner KH, Ang SL, Ikegami M, Finkelman FD, Stahlman MT, Fulkerson PC, Rothenberg ME, Whitsett JA. FoxA2 regulates alveolarization and goblet cell hyperplasia. Development 2004;131: 953-964.

65. Homer RJ, Zhu Z, Cohn L, Lee CG, White WI, Chen S, Elias JA. Differential expression of chitinases identify subsets of murine airway epithelial cells in allergic inflammation. Am J Physiol Lung Cell Mol Physiol 2006;291:L502-L511.

66. DeFelice M, Silberschmidt D, DiLauro R, Xu Y, Wert SE, Weaver TE, Bachurski CJ, Clark JC, Whitsett JA. TTF-1 phosphorylation is required for peripheral lung morphogenesis, perinatal survival, and tissue-specific gene expression. J Biol Chem 2003;278:35574-35583.

67. Park KS, Korfhagen TR, Bruno MD, Kitzmiller JA, Wan H, Wert SE, Khurana Hershey GK, Chen G, Whitsett JA. SPDEF regulates goblet cell hyperplasia in the airway epithelium. J Clin Invest 2007;117:978988.

68. Whiting PJ. The gabaa receptor gene family: new opportunities for drug development. Curr Opin Drug Discov Devel 2003;6:648-657. 
69. Xiang YY, Wang S, Liu M, Hirota JA, Li J, Ju W, Fan Y, Kelly MM, Ye $\mathrm{B}$, Orser B, et al. A gabaergic system in airway epithelium is essential for mucus overproduction in asthma. Nat Med 2007;13:862-867.

70. Patel AC, Brett TJ, Holtzman MJ. The role of CLCA proteins in inflammatory airway disease. Annu Rev Physiol 2009;71:425-449.

71. Hamann M, Gibson A, Davies N, Jowett A, Walhin JP, Partington L, Affleck K, Trezise D, Main M. Human Clca1 modulates anionic conduction of calcium dependent chloride currents. J Physiol 2009;15: 2176-2190.

72. Young HW, Williams OW, Chandra D, Bellinghausen LK, Perez G, Suarez A, Tuvim MJ, Roy MG, Alexander SN, Moghaddam SJ, et al. Central role of muc5ac expression in mucous metaplasia and its regulation by conserved 5' elements. Am J Respir Cell Mol Biol 2007; 37:273-290.

73. Wen FQ, Kohyama T, Liu X, Zhu YK, Wang H, Kim HJ, Kobayashi T, Abe S, Spurzem JR, Rennard SI. Interleukin-4- and interleukin-13enhanced transforming growth factor-beta 2 production in cultured human bronchial epithelial cells is attenuated by interferon-gamma. Am J Respir Cell Mol Biol 2002;26:484-490.

74. Cohn L, Homer RJ, Niu N, Bottomly K. T helper 1 cells and interferon gamma regulate allergic airway inflammation and mucus production. J Exp Med 1999;190:1309-1318.

75. Heller NM, Matsukura S, Georas SN, Boothby MR, Rothman PB, Stellato C, Schleimer RP. Interferon-gamma inhibits STAT6 signal transduction and gene expression in human airway epithelial cells. Am J Respir Cell Mol Biol 2004;31:573-582.

76. Shi ZO, Fischer MJ, De Sanctis GT, Schuyler MR, Tesfaigzi Y. IFNgamma, but not fas, mediates reduction of allergen-induced mucous cell metaplasia by inducing apoptosis. J Immunol 2002;168:4764-4771.

77. Stout BA, Melendez K, Seagrave J, Holtzman MJ, Wilson B, Xiang J, Tesfaigzi Y. STAT1 activation causes translocation of Bax to the endoplasmic reticulum during the resolution of airway mucous cell hyperplasia by IFN-gamma. J Immunol 2007;178:8107-8116.

78. Barnes PJ, Ito K, Adcock IM. Corticosteroid resistance in chronic obstructive pulmonary disease: inactivation of histone deacetylase. Lancet 2004;363:731-733.
79. Wenzel S, Wilbraham D, Fuller R, Getz EB, Longphre M. Effect of an interleukin-4 variant on late phase asthmatic response to allergen challenge in asthmatic patients: results of two phase 2a studies. Lancet 2007;370:1422-1431.

80. Boguniewicz M, Martin RJ, Martin D, Gibson U, Celniker A, Williams M, Leung DYM. The effects of nebulized recombinant interferongamma in asthmatic airways. J Allergy Clin Immunol 1995;95:133-135.

81. Nguyen LP, Omoluabi O, Parra S, Frieske JM, Clement C, AmmarAouchiche Z, Ho SB, Ehre C, Kesimer M, Knoll BJ, et al. Chronic exposure to beta-blockers attenuates inflammation and mucin content in a murine asthma model. Am J Respir Cell Mol Biol 2008;38:256-262.

82. Nguyen LP, Lin R, Parra S, Omoluabi O, Hanania NA, Tuvim MJ, Knoll BJ, Dickey BF, Bond RA. Beta2-adrenoceptor signaling is required for the development of an asthma phenotype in a murine model. Proc Natl Acad Sci USA 2009;106:2435-2440.

83. Singh BN, Whitlock RM, Comber RH, Williams FH, Harris EA. Effects of cardioselective beta adrenoceptor blockade on specific airways resistance in normal subjects and in patients with bronchial asthma. Clin Pharmacol Ther 1976;19:493-501.

84. Boskabady MH, Snashall PD. Bronchial responsiveness to beta-adrenergic stimulation and enhanced beta-blockade in asthma. Respirology 2000;5: $111-118$.

85. Hanania NA, Singh S, El-Wali R, Flashner M, Franklin AE, Garner WJ, Dickey BF, Parra S, Ruoss S, Shardonofsky F, et al. The safety and effects of the beta-blocker, nadolol, in mild asthma: an open-label pilot study. Pulm Pharmacol Ther 2008;21:134-141.

86. Ziment I. Theophylline and mucociliary clearance. Chest 1987;92: 38S-43S.

87. Rogers DF. The role of airway secretions in copd: pathophysiology, epidemiology and pharmacotherapeutic options. COPD 2005;2: 341-353.

88. Chen G, Korfhagen TR, Xu Y, Kitzmiller J, Wert SE, Maeda Y, Gregorieff A, Clevers H, Whitsett JA. SPDEF is required for mouse pulmonary goblet cell differentiation and regulates a network of genes associated with mucus production. J Clin Invest 2009;119:2914 2924. 